\title{
THREATENED MASCULINITY IN ARTHUR CONAN DOYLE'S IMPERIALIST DETECTIVE FICTION: THE SIGN OF FOUR
}

\section{ARTHUR CONAN DOYLE'UN THE SIGN OF FOUR ADLI EMPARYALIST DEDEKTIF HIKKAYESINDE TEHLIKE ALTINDAKİ ERKEKLİK}

\author{
Enes KAVAK ${ }^{1}$
}

\begin{abstract}
Arthur Conan Doyle's famous work The Sign of Four was published in Lippincott's Magazine in 1890, which proved to be one of the most praised works of all the stories written by the author. In contrast to the romance and adventure novels of the last decade of the nineteenth century, Doyle preferred London as his favourite setting for the adventures of his world-famous character Sherlock Holmes. In this story, Doyle's imperialist standpoint becomes a means of assurance for the male readers regarding the sense of order and re-establishment of the male authority by a rich portrayal of different forms of masculinities. This article thus aims to show how The Sign of Four offers a world of masculinities represented by different characters including the protagonist Sherlock Holmes and to what extent these representations challenge or adopt the common discourse about men's masculine role in the adventure stories of the era.
\end{abstract}

Keywords: Arthur Conan Doyle, The Sign of Four, Masculinity, Representations, Male Adventures.

$\ddot{O} z$

1890 yllında Lippincott dergisinde yayımlanan Arthur Conan Doyle'un ünlü eseri The Sing of Four (Dörtlerin İşareti), yazarın hikayeleri arasında en çok övgü alan eserlerinden biri olduğunu kanıtlamıştır. On dokuzuncu yüzyllın son on yllında, romans ve macera romanlarının aksine, Doyle dünyaca ünlü karakteri Sherlock Holmes'un maceraları için, en sevdiği yer olan Londra'yı mekan olarak tercih etmiştir. Bu hikayede, Doyle'un emperyalist bakış açısı, farklı erkeklik temsillerinin zengin bir tasviri ile kurulu düzen ve erkek otoritesinin yeniden kurulması ile, erkek okuyucu algısının güvencesi olmuştur. Bu makale, bu yönüyle, Dörtlerin İsareti'nin kahramanı Sherlock Holmes'inde dahil olduğu farklı karakterlerle temsil edilen bir erkek dünyası sunmaktadır ve bu temsillerin ne ölçüde bir meydan okuma olduğunu ve ayrica dönemin

\footnotetext{
${ }^{1}$ Arş. Gör. Dr., Gaziantep Üniversitesi, eneskavak@gmail.com
} 
macera hikayelerinin sundukları erkek rolüne dair ortak bir söylemin ne ölçüde benimsediğini göstermeyi amaçlamaktadır.

\section{Anahtar Kelimeler: Arthur Conan Doyle, Dörtlerin İsareti, Erkeklik, Temsiller, Erkek Maceraları.}

\section{INTRODUCTION}

The Indian treasure, the curious plan found among Morstan's baggage, the strange scene at Major Sholto's death, the rediscovery of the treasure immediately followed by the murder of the discoverer, the very singular accompaniments to the crime, the footsteps, the remarkable weapons, the words upon the card, corresponding with those upon Captain Morstan's chart - here was indeed a labyrinth in which a man less singularly endowed than my fellow-lodger might well despair of ever finding the clue. (Doyle, 2001: 51)

In his account of suspenseful events, Dr. Watson indicates how intimately Sir Arthur Conan Doyle's The Sign of Four (1890) shares a common ground with the adventure fiction of the $19^{\text {th }}$ century. After an indisputable supremacy of three-decker novels over other genres throughout the Victorian era, the last decade of the century brought about a literary revolution with the impact of social, political and scientific phenomena. By and large, it was an epoch of a noticeable deviance from what was thought to be conventional and conservative. The aestheticism of the Wildean drama, feminist sentiments of the New Woman's stories and masculine narratives of romance fiction shaped the literary sphere remarkably at fin-de-siècle (the last decade of the $19^{\text {th }}$ century). Particularly, male romance writers devised their narratives, merging romance and adventure elements into a new genre later called the "quest romance" or "the imperialist romance" (Patteson, 1981: 1). Most male authors constructed their stories with an emphasis on masculine virtues. Observing the characteristics of these novels, Elaine Showalter provides us with a portrait of the genre:

In various ways, these stories represent a yearning for escape from a confining society, rigidly structured in terms of gender, class, and race, to a mythologized place elsewhere where men can be freed from the constraints of Victorian morality. In the caves, or jungles, or mountains of this other place, the heroes of romance explore their secret selves in an anarchic space which can be safely called the "primitive". (Showalter, 1990: 81)

This masculine fantasy finds its embodiment in the settings of Sir Henry Rider Haggard's Africa, Rudyard Kipling's India or Robert Louis Stevenson's South Pacific Islands. Doyle, on the other hand, chooses London for his protagonist's adventures, in which he creates an imaginary territory, reminding us those of the Orient. Dr. Watson's narration also contributes to the fictional atmosphere of London, where some of inhabitants are from the colonial settings: Hindu servants, street Arabs and African aborigines. On the route to Sholto's house, Watson resembles their journey to a quest, referring to the houses, the "labyrinth of streets", “interminable lines of ... brick buildings" as "the monster tentacles' of the giant city" (Doyle, 2001: 23). By 
drawing a romanticised and mystified setting, Doyle appears to legitimise the urban space for the masculine fantasies of his male characters. Men, in this setting, are liberated from the restrictions of civilised society in an attempt to set off for their unfulfilled dreams in the shadowy and undiscovered parts of the city. The book Writing the Urban Jungle outlines that

'in its versatility, the literature of the "urban" cesspool or jungle, like the more traditional "literature of imperialism," does not just describe a locale of submission, but also an imaginative domain that calls forth heroic action: exploring, conquering, enlightening, purifying, taming, besting'. (McLaughlin, 2000: 3)

Apart from this, London is significant as the capital of the British Empire; thus being the symbol of the supremacy and power of Britain over its colonies. It should be noted that The Sign of Four was published "in a context of instability, unrest, anxiety about the Empire" (Kestner, 1997: 12). Thus, "Holmes' work first traces, then contains and controls, the disruptive colonial contaminations of the metropolitan space" (Keep and Randall, 1999: 217). In such a context, Doyle's imperialist detective fiction becomes a means of assuring the male readers as to the sense of order and re-establishing the masculine authority in their minds by offering a rich portrayal of different forms of masculinity in the story.

\section{REPRESENTATIONS OF MASCULINITY IN THE SIGN OF FOUR}

Doyle, in The Sign of Four, initially offers us a paradigm of masculinity via his creation of an ideal detective hero. This, first and foremost, is manifested in the qualities of detective profession, which can be credited to Sherlock Holmes' systematic method of crime investigation, didactic attitude towards his companion as well as reserved but authoritarian personality. With respect to the changing dynamics of the Victorian age, Jann (1995: 5) records that "the middle classes gained in economic and political power during the nineteenth century, they consolidated their cultural authority by remodelling the definition of the gentleman". Doyle, via his hero Sherlock Holmes, aims to offer us the representation of the ideal gentility, so Holmes should be regarded as a product of the popular Victorian vision: scientific rationalism and the selfhelp culture. Kestner (1997: 2) specifically defines the tales of Sherlock Holmes as "constructing a masculine script, given that they confirmed qualities which were radically gendered as masculine in Victorian culture: observation, rationalism, factuality, logic, comradeship, daring and pluck". In The Sign of Four, Holmes insistently places emphasis on the masculine virtues of his profession. In his eyes, "detection is, or ought to be, an exact science and should be treated in the same cold and unemotional manner" (Doyle, 2001: 7). Ostensibly he despises any traces of romanticism in his occupation and endorses a dedication to rational scientific reasoning. Nonetheless, Holmes is not flawless but even ambiguous in his character; and behind his logical and firm figure lays the traces of a conflicting personality. During a conversation with Watson on his long-run addiction to morphine and cocaine, he expresses his inner discontent with the real world:

My mind ... rebels at stagnation. Give me problems, give me work, give me the most abstruse cryptogram, or the most intricate analysis, and I am in my proper atmosphere. I can dispense then 
with artificial stimulants. But I abhor the dull routine of existence. I crave for mental exaltation. That is why, I have chosen my own particular profession, or rather created it, for I created it, for I am the only one in the world. (Doyle, 2001:6)

Holmes' conflicted character re-echoes the fact that the last decade of the century, when Doyle published his story, was rather chaotic and perplexing thanks to the colonial unrest, working-class strikes and changing gender roles. He, we may suggest that, presents a synthesis of two different characters: the masculine hero and the Decadent of Fin-de-Siècle. On the one hand, he is rational and a sample for superhuman; on the other hand, he is depressed, artistic and effeminate. His ability to disguise himself and his interest in the violin indicates his ambivalent and two-facet characters as a protagonist. However, Holmes cannot distance himself from the unconscious crisis of masculinity of his time. This ambiguity can also be aligned with the vague scheme of the story. Holmes "moves from the drug, to work, to imperial narrative and back to the drug. Even as one substitutes the drug for work, so the Mutiny narrative, the story of empire, stands in for the work of imperial management" (Keep and Randall, 1999: 219).

Nevertheless, Dr. Watson's presence in the story serves to a different end. At first glance, he is the embodiment of conventional masculine traits: he is a reliable doctor, a gentleman and a good companion to the Great Detective. Moreover, his narration contributes to the sense of mystery and romanticism in the story. He basically provides the reader with a romanticized and masculine spectacle of events, conflicting with Holmes' pragmatic attitude. Being a companion to Holmes, Watson is at the same time an admirer and follower of the former's extraordinary wit. Kestern (1997: 16), on Watson's importance in the novel, notes that “Carlyle's on Heroes, Hero-Worship, and the Heroic in History was decisive in forming the basic attitude of Watson to Holmes, as is frequently revealed by his expressions of adulation, amazement and admiration in many of the tales of the Holmes canon". Conversely, Holmes often reacts adversely to Watson's romantic nature and even despises his publication of a paper on their previous adventure due to his avoidance of factual aspects: "You have attempted to tinge it with romanticism, which produces much the same effect as if you worked a love-story or an elopement into the fifth proposition of Euclid" (Doyle, 2001: 7).

Holmes is not the only person suffering from a crisis of masculinity, but Watson appears to be sharing a similar misery due to his past experiences in the Afghan War and his wounded leg as a reminder of those days. Kestern (1997: 22) again underlines that, "Doyle has his narrator at one of the worst defeats the British troops suffered during the century", so this trauma signifies a more general strain on the male characters and imperial authority as well in a larger context. Haunting reminiscences of the past seem to reappear in the form of the character's insecurities. In Freudian terms, this unconscious anxiety which seems to have been instigated by this symbolic wound may possibly be explained as the oedipal anxiety of loss of manhood. In the story, each time Watson intends to confront Holmes' didactic manners and his cocaine addiction, he surrenders to a sense of frustration owing to Holmes' indomitable and rather queer personality:

I was annoyed at this criticism of a work which had been specially designed to please him. I confess, too, that I was irritated by the egotism which seemed to demand that every line of my pamphlet 
should be devoted to his own special doings. I made no remark, however, but sat nursing my wounded leg. I had a Jezail bullet through it sometime before, and though it did prevent me from walking it ached wearily at every change of the weather. (Doyle, 2001: 7).

This overwhelming repression persists in the course of the story. Miss Morstan's potential wealth with her share in the stolen treasure triggers Watson's emotional pain in the form of a financial inadequacy. The idea that she would be unreachable as a wealthy woman aggravates his inner sense of disillusionment:

Was it fair, was it honourable, that a half-pay surgeon should take such advantage of an intimacy which chance had brought about? Might she not look upon me as a mere vulgar fortune-seeker? ...

This Agra treasure intervened like an impassable barrier between us (Doyle, 2001: 50).

Worth noting that, towards the end of the Victorian era, the middle-class men had to face an identity crisis assuming that they had been losing their mandate in both domestic and social sphere. Women were getting more liberated through the new legal rights. Also, The Empire was struggling with the colonial unrest and strikes became a part of the metropolitan life and this created a sense of disillusionment was prevalent among men adventurers and war veterans. All in all, Watson's trauma, rather than a straightforward despair, refers to a more general phenomenon amidst the unprecedented change.

Another notable point as to Doyle's masculine narrative strategy in The Sign of Four is his emphasis on male autonomy and avoidance of active female representation. Richard F. Patteson (1981: 1) argues that in the typical imperialist romance, first popularized by H. Rider Haggard, a band of white men enters a primitive region and ultimately establishes a degree of influence among the natives. These male-oriented narratives are intended to assign women a supportive, idle and secondary role. In many cases, the male protagonist of the imperialistic romance is characteristically an evident misogynist, or as an alternative, female characters are portrayed as feeble and helpless in nature. Sherlock Holmes' seclusion and rejection of any female interference in his affairs can be grounded on this assertion. His account of women comprises abhorrence and distrust to such an extent that no other man could arouse in the same way.

'It is of the first importance,' he cried, 'not to allow your judgement to be biased by personal qualities. A client is to me a mere unit, a factor in a problem. The emotional qualities are antagonistic to clear reasoning. I assure you that the most winning woman I ever knew was hanged for poisoning three little children for their insurance-money, and the most repellent man of my acquaintance is a philanthropist who has spent nearly a quarter of a million upon the London poor.' (Doyle, 2001: 17)

Male bonding and companionship are offered as substitutes for heterosexual relationships or feminine intrusion in The Sign of Four as a characteristic of the period. The prospect of a marriage between Watson and Miss Morstan recalls the issue once more at the end of the novel. In Holmes' world there is no place for heterosexual relationship inasmuch as "love is an emotional thing, and whatever is emotional is opposed to that true cold reasoning which [he] place[s] above all things" (Doyle, 2001: 117). This type of union prevails among almost all male characters in the story. As well as Sherlock Holmes and Dr. Watson's alliance, nearly all male characters act in accordance with Doyle's strategic emphasis on the male union. As the title of story 
initially implies, The Sign of Four stands for the comradeship of four men: three Sikh men and an Englishman, Jonathan Small, all of whom vow to stick to their bond. Likewise, on the popularity of type of relationship, John Tosh (1999: 189) suggests that

Late Victorian manliness was a public, even military, code, to be exercised among men. Relations with the other sex were taken granted, or else subsumed by a ritual call to chivalry. 'Purity' was promoted as a call to cleanness - a perfect manhood - rather than a moral obligation towards women.

In his respect, Conan Doyle intentionally draws a portrait of masculine comradeship, embracing the values such as courage, self-control and trustworthiness. Small's insistence on his loyalty to his vow reflects his wish for exhibiting these manly traits saying "we should each always act for all, so that none might take advantage. This is an oath that I can put my hand on my heart and swear that I have never broken" (Doyle, 2001: 107).

There are two underlying reasons for why such a bond transcends conventional male-female relationships. Principally, male rejection of female friendship stems from the idea that women are unpredictable and unfaithful in nature, so they cannot be relied upon. They should always be under control and never violate the masculine sphere. Accordingly, in the imperialist romance, women are frequently attributed with many negative qualities such as "weakness, cowardice, treachery and lasciviousness" (Patteson, 1981: 5). Secondly, for men, the colonial life promised a homosocial paradise, governed by clearcut masculine values, where life was not subject to constant negotiation with the opposite sex (Tosh, 2005: 208). This offered a chance for men to break from the chains of civilization and discover a new life without the boundaries of domestic life. In view of that, this new life provided them with the opportunity they had craved for ages for sexual and autonomous adventure.

A final manifestation of masculinity in The Sign of Four can be interpreted as the masculine desire to keep control of domestic and colonial life. This intention is generated from a deep anxiety about domestic violence and colonial upheaval. During the $19^{\text {th }}$ century, upper and middle classes kept a constant fear of a revolt against the values they stood for. Anne McClintock (1995: 118) asserts that

In the last decades of the nineteenth century, the urban crowd became a recurring fetish for ruling class fears of social unrest and underclass militancy. Lurking in the resplendent metropolis, the crowd embodied a "savage" and dangerous underclass waiting to spring upon the propertied classes. Similarly, in Doyle's fiction, as in many other Victorian writers' works, there is an indication of the common fear as to the upheaval of the inferior and the degenerated: working-class people within and colonial races outside the Empire. Thanks to these pervasive anxieties, the need for an authoritarian body to monitor and regulate criminals in cities is embodied in detective genre. Holmes claims himself to be "the last and the highest court of appeal in detection" (Doyle, 2001: 6), which both indicates his privileged position beyond legal institutions and established laws and also points to "a reinscription of boundaries, and often a deliberate transgression of, or penetration into, the space of the other" (Dixon, 1995: 156). Beyond that, Sherlock 
Holmes' masculine authority on criminals suggests a further allusion to the imperial desire to control the colonies. The mutiny itself constitutes a problematic issue in Doyle's text. Keep and Randall (1999: 212) credibly note on the issue that

The compulsive, almost obsessional need to bring the Mutiny to account, to register every detail of its origins and to explain what could have brought about such unimaginable "treachery" and "villainy", is indicative of the extent to which the uprisings of 1857-58 challenged British claims to colonial authority. From the mid-nineteenth century and well into the twentieth, the Indian uprisings have been insistently portrayed as "mutiny", as a revolt against a putatively legitimate, military authority.

In The Sign of Four, one of the characters Jonathan Small declares that "there were two hundred thousand black devils and the country was a perfect hell" and "these men that we fought against, foot, horse and gunners, were our picked troops, whom we had taught and trained" during the Indian Mutiny, which stresses the political instability in colonial lands (Doyle, 2001: 98-99). Doyle's text clearly argues that this case sets a clear threat to masculine military power. Being a pointer of the fears of the Victorian man, Holmes quotes as to the aborigines of the Adaman Islands from a gazetteer:

They are a naturally hideous, having large, misshapen heads, small fierce eyes, and distorted features. ... They have always been a terror to shipwrecked crews, braining the survivors with their stone-headed clubs or shooting them with their poisoned arrows. These massacres are inevitably concluded by a cannibal feast. (Doyle, 2001: 69)

Watson's account of the native Tonga in the boat during their pursuit along the Thames accentuates this concern and instinctive desire to put it under the control. Watson describes "a little black man ... with a great, misshapen head and a shock of tangled, disheveled hair ... features so deeply marked with all bestiality and cruelty" (Doyle, 2001: 86). A similar sense of terror is repeated in many contemporary romance fictions. Therefore, the so-called inferior races pose a possible threat against the established orders: the stability of the Empire and the white man's masculine authority over the domestic sphere.

\section{CONCLUSION}

The imperialist romance was the dominant popular literary form of an immensely powerful ruling class which continues to influence our lives in countless ways even today (Patteson, 1981: 4). Being a quintessential of Doyle's detective genre, The Sign of Four presents numerous issues relating to the late Victorian quest romance pertaining to manhood and masculine narration. Sherlock Holmes is undoubtedly the epitome of the idea of true masculinity of his age - being courageous, rational and unemotional. All these qualities reside in Holmes' scientific profession and obscure personality. It is not surprising that the Holmes stories constituted a popular series for middle and working-class men. As Kestner (1997: 14) argues that 
the representation of the male in Conan Doyle's Sherlock Holmes texts constitute a dimension of this 'male spectacle' for Victorian culture, whereby the formation of masculinity and negotiation of ideas of manliness can be represented to the bourgeois readership of journals such as the Strand.

Nevertheless, The Sign of Four, as Doyle's other detective stories, cannot avoid portraying the conflict and disillusionment of middle-class manliness at the turn of the nineteenth century, which is exemplified in Holmes' blurred sexuality. Dr. Watson, however, should be regarded as a credible character with his persistent anxiety, prejudices and romantic affair with Miss Morstan. As in the imperial romances of the period, Doyle places emphasis on male bonding and the disarticulation of the feminine subject. Doyle's embracement of the active and dominant manliness in the book also means his exclusion of the female characters from the social sphere, which thus aligns him with other popular romance writers like Haggard, Stevenson or Conrad. By and large, Doyle's masculine narrative underpins the idea of the imperial power and domestic order. However, this imperialistic posture also discloses a problematical narrative strategy conflicted with contemporary scientific and political prejudices against other races and the poor classes in the 1890 s. Accordingly, Doyle's detective fiction is deeply coded with a Victorian masculine worldview on gender, race and nation.

\section{REFERENCES}

Dixon, Robert (1995), Writing the Colonial Adventure: Race, Gender and Nation in Anglo-Australian Popular Fiction, 1875-1914, Cambridge University Press, New York.

Doyle, Arthur Conan (2001), The Sign of Four, Penguin Classics, London.

Jann, Rosemary (1995), The Adventures of Sherlock Holmes: Detecting Social Order, Twayne Publishers, New York.

Keep, Christopher, and Randall, Don (1999), “Addiction, Empire and Narrative in Arthur Conan Doyle’s The Sign of the Four", Novel: A Forum of Fiction, Say1. 32, No. 2, (207-221).

Kestern, Joseph A. (1997), Sherlock's Men: Masculinity, Conan Doyle and Cultural History, Ashgate Publishing Limited, Hants.

McLaughlin, Joseph (2000), Writing the Urban Jungle: Reading Empire in London from Doyle to Eliot, Virginia University Press, Charlottesville and London.

McClintock, Anne, (1995), Imperial Leather: Race, Gender, Sexuality in the Colonial Contest, Routledge, London.

Patteson, Richard F. (1981), "Manhood and Misogyny in the Imperialist Romance”, Rocky Mountain Review of Language and Literature, Say1. 35, No. 1, (3-12).

Showalter, Elaine (1990), Sexual Anarchy: Gender and Culture at the Fin de Siècle, Virago Press, London. Tosh, John (1999), A Man's Place: Masculinity and the Middle-Class Home in Victorian England, Yale University Press, Bath. 